\title{
Defining shear zone boundaries using fabric intensity gradients: An example from the East-Central Nepal Himalaya
}

\section{- Supplementary Material}

\author{
K. Larson, J. Cottle, G. Lederer, S.M. Rai
}

\section{Contents of this file}

Geochronologic Methods

Geochemical Methods

Figure S1

Table S1 - separate spreadsheet file

Table S2

\section{Geochronologic Methods}

Zircon from specimens PK45, 39, 51, and 57 were analyzed by LA-MC-ICPMS at the University of California in Santa Barbara. Full details of the analytical procedure can be found in Cottle et al. (2013, 2012). U-Th/Pb analyses were conducted for 30s each using a spot diameter of 20 $\mu \mathrm{m}$, a frequency of $4 \mathrm{~Hz}$, and $1.0 \mathrm{~J} / \mathrm{cm}^{2}$ fluence (equating to crater depths of $\sim 6 \mu \mathrm{m}$ ). Data reduction, including corrections for baseline, instrumental drift, mass bias, down-hole fractionation, and uncorrected age calculations, and concentration calculations were performed using Iolite version 2.5. Full details of the data reduction methodology can be found in Paton et al. (2010) and Cottle et al. (2012). Age data were plotted using Isoplot v.3.7 (Ludwig, 2003) and Redux version 2.20.39 (Bowring et al., 2011).

A primary reference zircon "91500" (1065 Ma ${ }^{206} \mathrm{~Pb} /{ }^{238} \mathrm{U}$ isotope dilution-thermal ionization mass spectrometry (ID-TIMS) age (Wiedenbeck et al., 1995)), was employed to monitor and correct for mass bias as well as $\mathrm{Pb} / \mathrm{U}$ down-hole fractionation. To monitor data accuracy, two secondary reference zircon "GJ1" (601.7 $\pm 1.3 \mathrm{Ma}$, D. Condon unpublished ${ }^{206} \mathrm{~Pb} /{ }^{238} \mathrm{U}$ ID-TIMS age) and "Plešovice" (337.13 $\pm 0.37 \mathrm{Ma}{ }^{206} \mathrm{~Pb} /{ }^{238} \mathrm{U}$ ID-TIMS age) (Sláma et al., 2008) were analyzed concurrently (once every five unknowns) and mass bias- and fractionation-corrected based on measured isotopic ratios of the primary reference material. During the analytical period, repeat analyses of GJ-1 and Plešovice yielded weighted mean ${ }^{206} \mathrm{~Pb} /{ }^{238} \mathrm{U}$ ages of $601 \pm$ $1 \mathrm{Ma}(\mathrm{MSWD}=1.1)$ and $338 \pm 6(\mathrm{MSWD}=1.7)$, respectively.

\section{Geochemical Methods}

Whole rock geochemistry of the specimens was derived through X-Ray Fluorescence of fused beads prepared from specimen poweders using a PANalytical Axios FAST WDXRF spectrometer at Pamona College in Claremont, California.

\section{Bibliography}


Bowring, J.F., McLean, N.M., and Bowring, S., 2011, Engineering cyber infrastructure for U-Pb geochronology: Tripoli and U-Pb_Redux: Geochemistry Geophysics Geosystems, v. 12, doi: 10.1029/2010GC003479.

Cottle, J.M., Burrows, A.J., Kylander-Clark, A.R., Freedman, P.A., and Cohen, R.S., 2013, Enhanced sensitivity in laser ablation multi-collector inductively coupled plasma mass spectrometry: Journal of Analytical Atomic Spectrometry, v. 28, p. 1700-1706, doi: 10.1039/c3ja50216c.

Cottle, J.M., Kylander-Clark, A.R., and Vrijmoed, J.C., 2012, U-Th/Pb geochronology of detrital zircon and monazite by single shot laser ablation inductively coupled plasma mass spectrometry (SS-LA-ICPMS): Chemical Geology, v. 332-333, p. 136-147.

Paton, C., Woodhead, J.D., Hellstrom, J.C., Hergt, J.M., Greig, A., and Maas, R., 2010, Improved laser ablation $\mathrm{U}-\mathrm{Pb}$ zircon geochronology through robust downhole fractionation correction: Geochemistry Geophysics Geosystems, v. 11, p. n/a, doi: 10.1029/2009GC002618.

Sláma, J., Košler, J., Condon, D.J., Crowley, J.L., Gerdes, A., Hanchar, J.M., Horstwood, M.S.A., Morris, G.A., Nasdala, L., Norberg, N., Schaltegger, U., Schoene, B., Tubrett, M.N., and Whitehouse, M.J., 2008, Plešovice zircon - A new natural reference material for U-Pb and $\mathrm{Hf}$ isotopic microanalysis: Chemical Geology, v. 249, p. 1-35, doi:

10.1016/j.chemgeo.2007.11.005.

Wiedenbeck, M., Alle, P., Corfu, F., Griffin, W.L., Meier, M., Oberli, F., Vonquadt, A., Roddick, J.C., and Speigel, W., 1995, Three Natural Zircon Standards for U-Th-Pb, Lu-Hf, Trace-Element and Ree Analyses: Geostandards Newsletter, v. 19, p. 1-23, doi: 10.1111/j.1751908X.1995.tb00147.x.

(Next Page) Figure S1 -AVA (left) and geometric quality (right) diagrams from the specimens analyzed in this study. Each is $30 \mathrm{~mm}$ x $20 \mathrm{~mm}$ and oriented with south to the left and north to the right side. Geometric quality is a measure of how well the position of the interpreted optical axis is defined. Quartz will generally have very high quality - light shade, while other mineral phases, such as mica, will have significantly poorer quality - darker shade. The color wheel on the left in the AVA diagram shows the orientation of the $c$-axis in a lower hemispherical projection. 

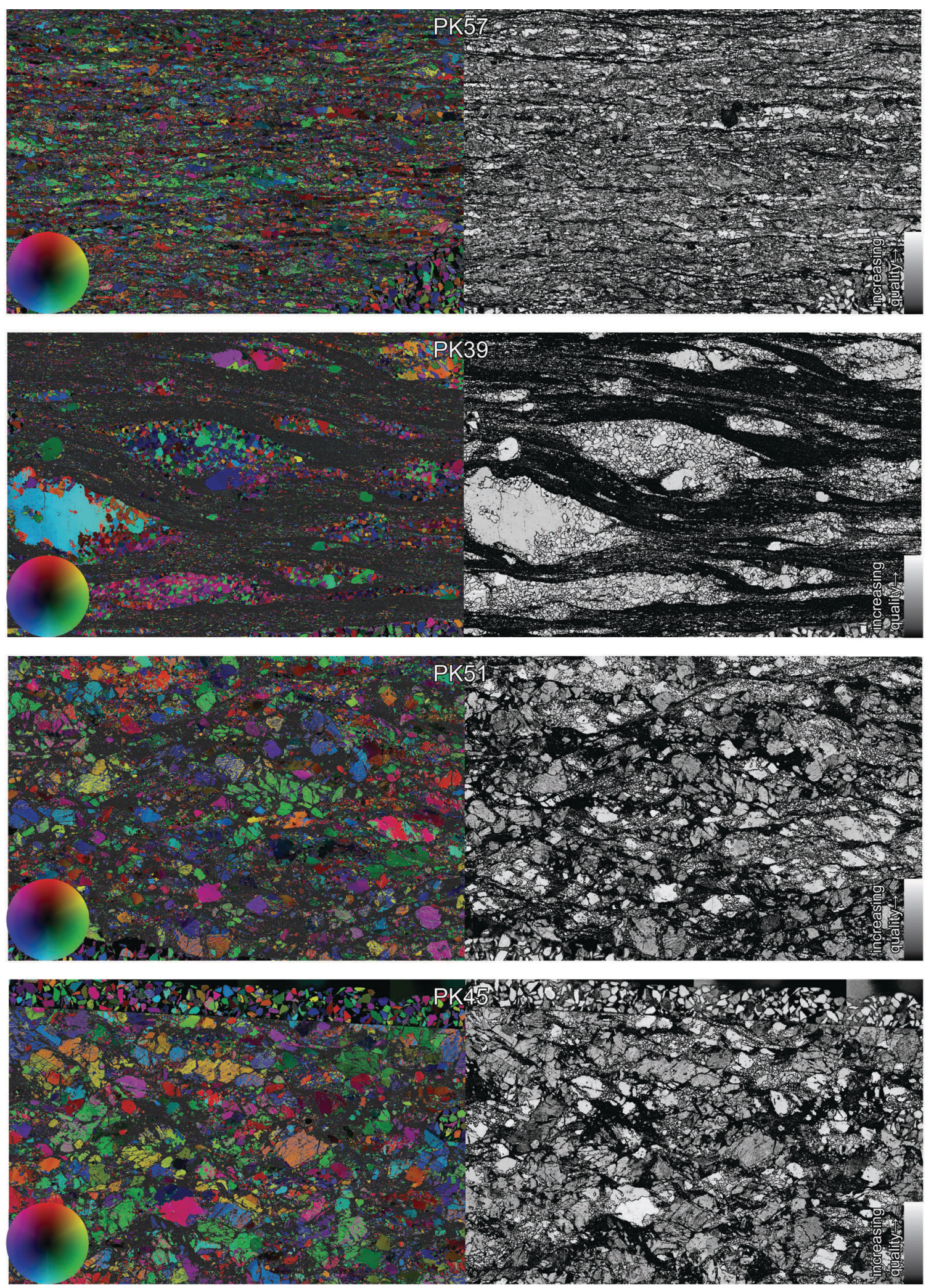
Table S1 - Available as a separate .xls file

Table S2

TABLE S2. GEOMETRIC PARAMETERS OF C-AXIS FABRICS

\begin{tabular}{|c|c|c|c|c|c|c|c|}
\hline \multirow[t]{2}{*}{ Specimen } & \multicolumn{3}{|c|}{ Eigenvalues } & \multirow{2}{*}{$P$} & \multirow{2}{*}{ G } & \multirow{2}{*}{$\mathrm{R}$} & \multirow{2}{*}{ B } \\
\hline & Axis 1 & Axis 2 & Axis 3 & & & & \\
\hline PK57 & 0.5682 & 0.2865 & 0.1453 & 0.2817 & 0.2824 & 0.4359 & 0.5641 \\
\hline PK39 & 0.4636 & 0.3240 & 0.2124 & 0.1396 & 0.2232 & 0.6372 & 0.3628 \\
\hline PK51 & 0.4199 & 0.3172 & 0.2629 & 0.1027 & 0.1086 & 0.7887 & 0.2113 \\
\hline PK45 & 0.4064 & 0.3056 & 0.2880 & 0.1008 & 0.0352 & 0.8640 & 0.1360 \\
\hline
\end{tabular}

Vollmer, F.W., 1990, An application of eigenvalue methods to structural domain analysis: Geological Society of America Bulletin, v. 102, p. 786-791. 